\title{
Making space for the 'post-secular' in religious studies
}

am greatly honoured to have the opportunity to say a few words at the opening of the annual Donner Institute Conference, which this year focuses on post-secular religious practices. ${ }^{*}$ Of course this challenging task made me think about my own connection to the notion of the secular, as well as its corollary, 'post-secular'. During the past twenty-five years, I have been working on the cultural logic of terms denoting 'the sacred'. My sincere wish has been to unravel both cultural and cognitive mechanisms by which the domains of the religious and the secular are established in social life in order to create distinctions, boundaries and behavioural rules for observing them. From the outset, the theory that I have proposed entails that the element of 'religion' or 'the sacred' is an inextricable ingredient in human societies, giving shape to diverse individual and culturally shared religious formations and mental landscapes. Even though I have theorised the sacred more in reference to vernacular cultures rather than theological religions, my primary goal has been to break open the fuzzy boundaries used to constitute the domain of the secular rather than to explore religion or the sacred per se. My methodological choices have been motivated by a conviction according to which the parameters forming a religion in a specific cultural setting need to be viewed in close connection with its counter-domain, 'non-religion. The parameters of faith are always in some specific relationship with ideas, ideologies, philosophies and political programmes underlying the domain of the secular. I have defined the sacred as a 'categorical boundary to set things with non-negotiable value apart from things whose value is based on continuous transactions' By means of this definition I have wanted to emphasise and point out that people in general have not only a culturally established inclination, but also an innate capacity to participate in distinct sacred-making activities and processes of signification according to paradigms given by the belief systems to which they are committed, be they religious, national or ideological (Anttonen 2000: $280-1)$.

* This paper is based on the words of welcome on 15 June 2011. Veikko Anttonen is Professor of Comparative Religion at the University of Turku. 
In close connection with my methodological choices, Kim Knott has suggested that the contours, beliefs, practices and culture of the secular have hardly begun to be researched (Knott 2010). We still need to flesh out the hidden mechanisms which create the boundary space between the domains of religion and non-religion and bring them into close interaction with each other in varying formations and discursive practices. By developing tools, methods and models for analysing the relationship between the 'religious' and the 'secular', scholars in the field of religious studies are better equipped to theorise these domains in juxtaposition with each other and to re-engage the study of religion with other disciplines (see Knott 2010:133). I am tempted to think that otherwise the whole enterprise of distinguishing certain religious practices and subsuming them in the corollary category of the 'post-secular' would be methodologically untenable.

There are various scholars of religion who have made important contributions to our understanding of the relationship between the two domains. Being one among the many, Timothy Fitzgerald identifies 'religion' and the 'secular' as being mutually conditioned, oppositional concepts which in a way similar to concepts such as 'economics' and 'politics', emerge in the context of western Enlightenment and colonialist discourse. Fitzgerald maintains that religion's other, the category of non-religion, appeared discursively in the guises of concepts such as 'superstition', the 'profane', the 'secular' and 'secularism' (Fitzgerald 2007a, 2007b). Our approaches and discourses as scholars of religion have suffered from a one-sided methodological attitude regarding the priority of one domain over the other. Classical secularisation theories are the outcome of this one-sidedness. Sociologists of religion have in recent years voiced critical responses and discontents in the secularist paradigm. The eminent British sociologist of religion, Grace Davie has challenged the long-established secular canopy according to which there is a necessary connection between modernisation and secularisation. Davie posits that the secularity of Europe is not a model for export. It is better to see Europe as an exceptional case, something distinct and peculiar to the European corner of the world, which cannot be treated as the norm in its secularity (Davie 2002). In addition to the former communist countries in East and Central Europe, where secularism was a dominant ideology, French secularism is a paramount example of the European case.

The American social anthropologist Peter R. Bowen gives a vivid illustration of the French category of the secular, laïcité, in his book Why the French Don't Like Headscarves, which has the subtitle 'Islam, the State and Public Space' (2007). In his ethnographic study, Bowen sets out to find reasons why 
a law was passed by the French Government in 2004 which prohibited any clothing that clearly indicated a pupil's religious affiliation. Bowen refers to views according to which it was not until the 1970 os that the Republican concept of laïcité became the general framework for French thinking about new social issues such as the nature of family, divorce, homosexuality and the acceptability of the Islamic headscarf. In France, laïcité, or secularity, revolves around the concept of the public. The public domain is defined in terms of an unquestionable allegiance to the state. The law prohibiting headscarves reveals fears and anxieties over the recognition of French Republican values. Bowen cites French historians, according to whom modernity in France necessitated an 'exit from religion'. The retreat of religion from the public space consisted of three simultaneous changes: religion ceased to suffuse the public world; God retreated to a position of absent power; and the individual assumed the right to choose to believe or not to believe. This modern revolution in religion was accompanied by a profound transformation of the state: the state became a moderator of arrangements among the individual participants in civil society. The freedom of individuals to choose their affiliations and attachments to churches, societies and labour unions was not in conflict with the republican model of the state. Regarding the ban on religious signs, Bowen comes up with an assumption that the headscarf wearer is making inappropriate public claims about the superiority of her values to those of other people. Rather than signifying only a choice of individual identity, the scarf sends a message that is out of place in modern society, because it involves absolute truth claims. Bowen concludes that 'When Muslim women in headscarves say that it is with these clothes and this religion that they choose to abide by the rules of the Republic and the life together (la vie commune) that is France' (Bowen 2007: 249), they challenge the conditions for belonging to the nation. Although this challenge creates anxieties about sociability and allegiance, anxieties over differences in appearance, history and religious ideas can lead to new possibilities for sharing a life together. Although Bowen does not use the concept, this new self-understanding of being and displaying Frenchness can be taken as an instance of an expression of 'post-secularity'. I hereby thank you for your attention and I wish you all an inspiring and successful conference! 
VEIKKO ANTTONEN

\section{References}

\section{Anttonen, Veikko}

2000 'Sacred'. In: Willi Braun \& Russell T. McCutcheon (eds), Guide to the Study of Religion. 271-82. London \& New York: Cassell.

\section{Bowen, John R.}

2007 Why The French Don't Like Headscarves: Islam, the State and Public Space. Princeton \& Oxford: Princeton University Press.

\section{Davie, Grace}

2002 Europe: The Exceptional Case. Parameters of Faith in the Modern World. London: Darton, Longman and Todd.

\section{Fitzgerald, Timothy}

2007a 'Introduction'. In: Timothy Fitzgerald (ed.), Religion and the Secular: Historical and Colonial Formations. 1-24. London \& Oakwille: Equinox.

2007b Discourse on Civility and Barbarity: A Critical History of Religion and Related Categories. Oxford: Oxford University Press.

\section{Knott, Kim}

2010 'Theoretical and methodological resources for breaking open the secular and exploring the boundary between religion and non-religion.' Historia Religionum: An International Journal 2: 115-33. 